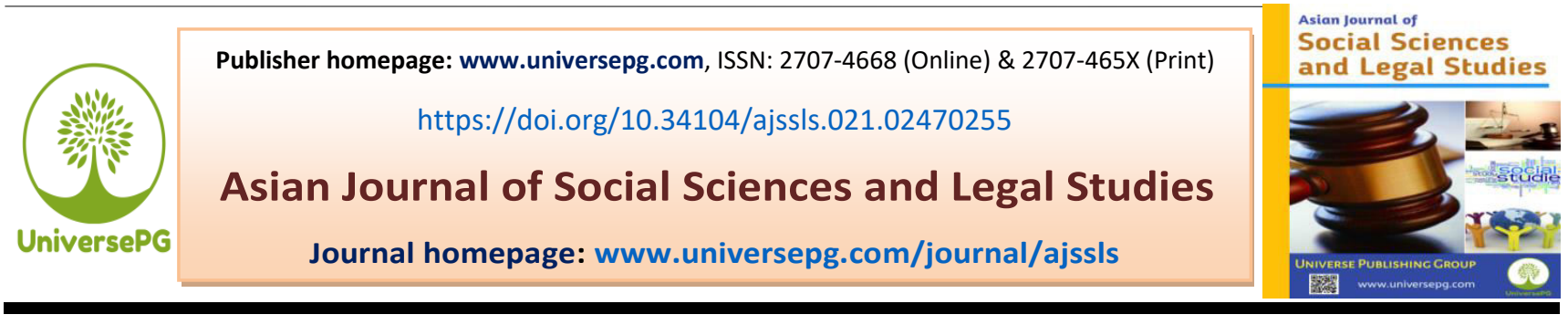

\title{
Contemporary Mainstream Bengali Movies and Societal Perceptions towards Rape: Legal Perspectives
}

\author{
Jannatul Shareat Disha ${ }^{1 \& 2} *$ \\ ${ }^{1}$ Department of Law and International Law, Bangladesh University of Professionals, Dhaka, Bangladesh; and ${ }^{2}$ MBA, \\ Beijing Normal University, Beijing, China. \\ *Correspondence: disha.bnu2021@gmail.com (Jannatul Shareat Disha, Dept. of Law and International Law, Bangladesh \\ University of Professionals, Dhaka, Bangladesh; and MBA, Beijing Normal University, Beijing, China).
}

\begin{abstract}
Incidents like the rape of late have been grabbing the spotlight which is one of the most significant challenges in Bangladesh. This paper aims to assess people's perceptions by establishing a link between movies and society. This paper goes on to discuss people's perceptions of rape as well as how rape is depicted in Bengali films. While addressing how these portrayals affect people's perceptions in general, this research will also address whether or not the film makers open themselves up to any social or legal responsibilities to society. As a result, this study sought to examine to extend a film could indeed change a viewer's perceptions and behaviour from a socio-legal context. This paper further briefly discusses the existing laws to prevent rape and censorship rules for Bengali Movies. The paper will identify the major setbacks in existing legal instruments and possible legal recourses to address the setbacks.
\end{abstract}

Keywords: Rape, Social legal recourse, Rape myths, Rape laws, and Bangladesh societal perceptions.

\section{INTRODUCTION:}

Movies or films are the reflections of the cultures of a country (Robert \& Douglas, 1995). It also portrays how a society reacts to the contemporary issues. Multifaceted trends coexist in a society. Among them, social perceptions of rape have demonstrated a consistent pattern of blaming victims and exonerating the offender, particularly when the offense is committed by someone close to the woman. Victim blaming is a common feature among these responses. Many factors seem to have influenced this distorted notion and the negative reactions directed at the victim.

Undoubtedly movies play an important role in encouraging many distorted conviction of the people in Bangladesh. This article first examines societal perceptions of rape. Thereafter, it revisits how films affect people's viewpoint about rape. Finally, it addresses the possible legal resources to resolve this problem (Faysal and Rahman, 2021).

\section{METHOLODOGY:}

This is a socio-legal study that incorporates both qualitative and quantitative methodologies. The qualitative part concerns retrieving facts and ideas from contemporary Bengali movies as well as analysing legal texts. The qualitative part concerns conducting survey among viewers of contemporary mainstream Bengali movies.

This empirical research takes into account recent mainstream commercial Bengali movies to find out how women are being portrayed in films which is very much similar to the notion of the audience. Producers get these notions from the society in which they live. The researcher watched 92 Bengali movies in order to determine the relationship between Bengali movies and rape culture or the societal perceptions about rape.

In addition, to gain better understanding male perceptions, researcher conducted a survey of 220 peoples 
from various professions (aged 18-40). The survey was administered by the researcher as a combination of quizzes and open-ended questions.

\section{Scope and limitations}

This is a small-scale study. Due to constraint of time and resources, particularly human resources, it was not possible to do a large scale survey for the purpose of this study. Only 220 people may not represent the majority of the population. The researcher recognizes these constraints as work limitations. The recommendations discussed here are solely based on the information obtained by the researcher during the 90-day research period. As a result, many of these recommendations include conducting additional research and data collection to back up the current process.

\section{A relation between movie portrayal and societal perceptions}

Movies are inarguably a great source of entertainment; watching movies help us escape from our daily lives. As per the survey, $82.73 \%$ of respondents interviewed watch Bengali movies on a regular basis. The number is evidently high. Many of us are moved by films because the combination of images, music, dialogue, lighting, sound, and special effects can evoke strong emotions and help us reflect on our lives. They can assist us in comprehending our own lives, the lives of those around us, and even how our society and culture function. It has always played a significant role in shaping our society and our perspectives. For instances, patriotic films remind us to love our country, adventure films inspire us to explore new possibilities, and good comedy films have treated many patients through laughter therapy and as such, it is evident that films has a power to bring about a change not only in the society but also in the perceptions of the people in the society. There are some films that has greatly impacted the society and brought changes. For instances, fight Club movie (Linson \& Fincher, 1999) gave an insight of a man who vents his frustrations about his boring, mainstream life by joining an underground fight club. After the release of the movie, real fight clubs have sprung up in the United States (Robinson, 2015) like the New York's underground fight circuit as well as in Russia and Bangkok, Thailand. The film 'Bambi' depicted a mother deer being killed by a hunter before her baby's eyes. After the film was in theatres, deer hunting in the US was cut in half. Moreover, the psychological impact resulted from UniversePG I www.universepg.com anthropomorphizing animals got a term on its term because of the movie (Pila, 2010). Another movie, JFK (Ho \& Stone, 1991) which was about the conspiracy theory of the assassination of President JohnF. Kennedy, it triggered not only a lot of public criticism. It brought a lasting reform in the assembly of the US Assassination Records Review Board and the creation of the President John F. Kennedy Assassination Records Collection Act of 1992 (National Archives, 2010). Another popular show on Netflix '13Reasons why' after the telecast of this show, a statistic was reported that, "SUICIDE" searches increased following the release of the show (CNN, 2017). These movies/shows demonstrate that movies indeed have an impact on people's thinking. Some films have such enormous potential that they alter public views. Some films have changed many different societal practices, while others have introduced new fashions and social trends.

\section{Societal perceptions of rape}

It is no surprise that women are almost always blamed for rape, despite a rapist may have motivations for committing rape. Rape causes a great deal of anguish for its victims, as well as their friends and families. Their misery is exacerbated by the prevailing social convictions about rape and women which will be explained in detail below.

\section{Women's liberation}

One societal conviction is that rape is motivated by women's liberty. It is believed that the more liberated a woman is, the more likely she is to face harassment and molestation. To avoid these occurrences, women should stay and never leave the house after dark. If they leave the house alone, it will be their own fault. According to the findings, one-third of rape cases occurred in deserted (Bohner et al., 2009) or isolated areas (Lonsway et al., 1994) and $46.82 \%$ respondents believe that women are easily targeted when they are alone (Akter et al., 2019).

\section{Stereotypical belief}

A widely held and clichéd but incorrect stereotype (Burt \& Martha, 1980) is that sexual violence is frequently instigated by an attractive, scantily and seductively dressed woman who is out alone. Many people believe that this kind of things provoke a man to commit sexual violence or rape against women (Lonsway et al., 1994) and incorrectly places the entire blame for a rapist's actions on the victim, further victimizing her in the process (Akhter et al., 
2005). According to statistics, acquaintance rape (Warsaw \& Parrot, 1991) is more common than stranger rape, and even a girl child is frequently a victim of sexual violence. It is confirmed by the survey that $50.91 \%$ of respondents blame rape victims for their attire. They think women should dress in shapeless head-to-toe black dresses with a mask and not to provoke sexual attacks. Even in Courts, rapists were acquitted on this ground that the victim had dressed 'provocatively' in jeans and t-shirt (Hildebrand \& Najdowski, 2015).

\section{Absence of justice}

Victims are no longer receiving the justice they deserve from the authorities. People do not report crimes to the police in the fear that the officers will not help them and the complaint procedure will further victimize them. What's more, to stall the investigation, police officers frequently claim that her family did not cooperate by providing information. Even when sufficient evidence is found, the police frequently ask the victim and the accused to settle the case. The police do nothing in the process and justice gets delayed (Al Azad et al., 2011). In this regard, a recent incident might well be mentioned. Shohagi Jahan Tanu, a 19-year-old college student, was murdered after being raped on March 20, 2016. Her body was discovered near a culvert in Kumilla's Mainamoti cantonment area, with signs of sexual assault prior to murder discovered in and on her body. People expressed their outrage through social media and street protests to get justice for Tanu's family, but to no avail. The police are yet to apprehend a rapist (Mehreen, 2016). An eight-month-old girl was raped in Gazipur and the police officer, told the media that they are trying their best to apprehend the rapist (ASK Report, 2017). This is how the authorities keep investigating these cases for a prolonged period whilst the victim family faces the worst. Later that year, a father committed suicide by jumping beneath a moving train with his 13-year-old daughter. For his daughter 'Ayesha' was sexually abused, and even after going to the police station several times, he failed to bring the issue under proper trial procedure. In this case, the absence of justice resulted in the death of a family (Daily Star, 2017).

\section{Prolonged judicial proceeding}

One of the reasons for the increased tendency of rape perceived to be the slowness of judicial proceedings. If our country's judicial system becomes more efficient, the rate of such offenses might well be signiUniversePG I www.universepg.com ficantly lowered. As discussed above, many cases or complaints do not see the light because of the prolonged process. Statistics says that the country records 300 rape cases per month out of which only $3.66 \%$ cases are resolved in a year, and only $4.5 \%$ accused are punished (Human Rights Report, 2017).

\section{Rape as a social taboo}

When a known person or relative commits rape, family members usually do not take legal action for fearing that reporting such incident, as in their investigation, is a disgrace that would tarnish the family's reputation. In majority cases, there is an inclination even on the part of the victim's family to hide such cases fearing the reactions or convictions of the society. For instances, it was reported in a leading newspaper that a raped girl was lashed 100 times since rape was a taboo in their community. For that reason she was whipped brutally (Prothom Alo, 2009). Same thing happened to another girl when the society got to know about the incident, she was sentenced to 202 lashes (Sheikh, Daily Star, 2010).

In Bangladesh, during 2016 about 724 women were raped and among them, 12 women were assaulted under Salish and Local dispute settlement in the village. Things did not stop there as these victims were further treated negatively by the local people. Such negative treatment includes cutting hair, physical torture (Local Human Rights Report 2016). Fearing these consequences of disclosure, women suppress their pain and anguish in silence.

\section{Abandoning traditional values}

Another erroneous belief is that rapes and sexual assaults occur because females of these days have abandoned their culture and became westernized. According to the survey, $82.73 \%$ of those polled believe that abandoning traditional values and modelling western behaviour contributes to rape. They genuinely think that by adopting ideologies, we are forgetting our own identity and ignoring the consequences. The community sees such gradual changes as factors that contribute to rape, social behaviours and relationships (Kogacioglu, 2011).

\section{Movie findings and contemporary trends of rape}

To analyse Bengali movies on societal convictions, the researcher watched films released between 2015 and 2018 and classified the findings into five major trends, which are listed below: 
Misinterpretation of women's politeness or silence In many Bengali films, men are shown misinterpreting a woman's politeness or friendliness. When a woman is nice to someone, they think of the girl as a very going, which is supported by $48.73 \%$ of those surveyed. For example, a character introduced as a really kind, sweet, and well-mannered girl named Rabu and the boy Chadu misinterpreted Rabu's friendliness. He mistook her smile for a signal of her 'easiness' and began misbehaving with her, inappropriately touching her (Akhter, 2015).

\section{Calling women with disgraceful names}

According to $80 \%$ respondents, body shaming and calling women names has become a popular trend that people has learnt from movies. Women are frequently mocked for how they appear, how they dress, and their assumed level of sexual activity. Women are frequently referred to as 'Maal' (an object/thing primarily used for entertainment) both in movies and in reality. In general, society believes that calling people names is normal in everyday life but in reality joking or having fun with others by calling names is a serious issue.

\section{Rape as a means to punish women}

This is no surprise that women many times have been punished by men as it is depicted in Bengali films. In many films, it was portrayed that a progressive woman was stopped by sexual assaults or molestation portraying it as a weapon to break her spirit. Such incidents have become a very common storyline in almost every movie (Khan, 2017).

\section{Isolated places and women's vulnerability}

Undoubtedly, whether in real life or on screen, society believes that a girl alone in a remote location is the best target. In movies, it is shown that the perpetrator waits for the girl to be alone or in a deserted area, and then uses golden opportunity to attack the girl, believing that nobody will be there to rescue (Alam \& Hayat, 2015).

\section{Objectification of women as a source of enter- tainment}

There is a delusional belief that if a film does not contain vulgarity or objectification of women as a source of entertainment, it will fail to draw an audience and thus fail to make money. According to $80 \%$ respondents, women are portrayed as a source of entertainment in Bengali films. The most glaring examples of portrayals of women as sex objects and men as sexual aggressors occur in movie songs where typically, females are shown dancing provocatively in scant and/or revealing clothes to gain men's attention (Faludi, 1991; Feldman et al., 1984). So, foregoing analysis, it is fairly obvious that in Bengali movies, women are portrayed as decorative objects, who must attract to be valuable, or as victims of men's sexual impulses. Either way, women are defined by their bodies and how men treat them (Davis \& D.M, 1990; Demare et al., 1988). Movies portray both in stereotypical ways, limiting human potential. When people see in movies where a woman is reprimanded by a man, they slowly start to believe that this is the proper way to be followed. It also encourages and promotes men being stronger than women while women being passive are always subjected to such violations. It alters people's attitudes and beliefs about society. As a result, it is clear that film industry adheres to a culture in which attitudes, norms, practices, and media normalize, excuse, and even encourage sexual violence against women.

\section{Survey result and data analysis}

To understand women's perceptions, this survey included approximately 220 people from various professions. Roughly $82.73 \%$ watch Bengali films on a regular basis, whereas $15.91 \%$ watch films on an infrequent basis. To put it mildly, respondents who believe films have an impact on people's minds is 92.73\% of respondents feel that films have an effect on people's minds. This segment focuses on the analysis of survey data to identify changing attitudes toward women by an influence of Bengali movies.

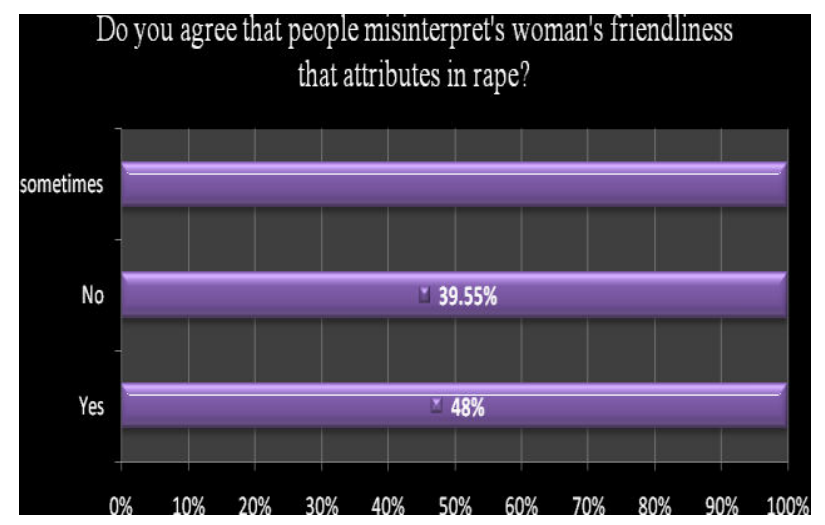

Fig 1: Misinterpretation of woman's friendliness.

As Fig 1 reflects, the survey finding indicates that $48 \%$ respondents believe that women's friendliness is misinterpreted, resulting in rape causation. Surprisingly, $11.82 \%$ agreed that people occasionally misinterpret women's friendliness, while $39.55 \%$ disagreed. Technically, approximately $50.91 \%$ respondents believe that a woman's friendliness contri- 
butes to rape causation. As demonstrated through Fig 2, a sizable proportion of respondents (53\%), the isolated area is not a requirement for committing rape, a disappointing finding. By contrast, $46.82 \%$ believe that isolated or deserted areas increase the likelihood of rapists committing the crime.

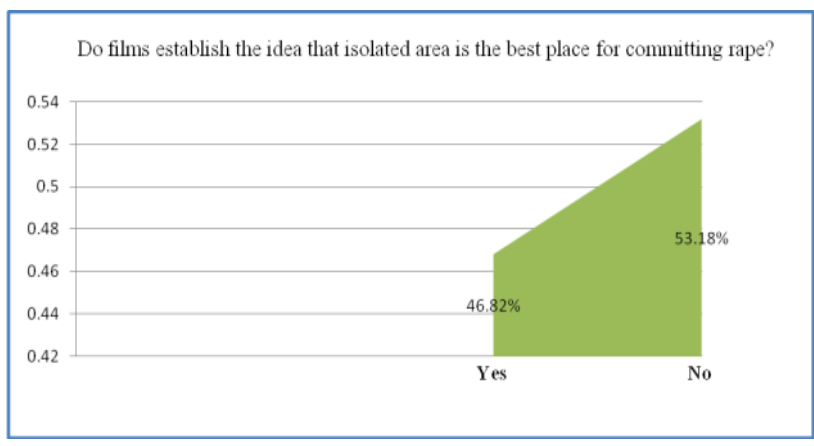

Fig 2: An isolated place is the most preferable place to commit rape.

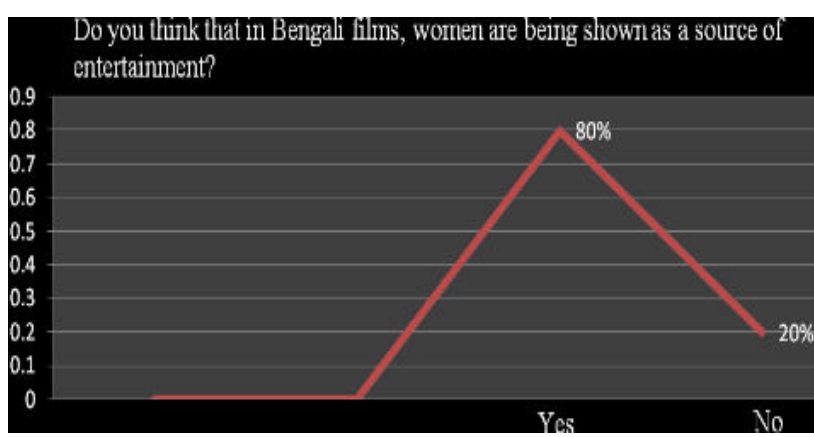

Fig 3: $80 \%$ Respondents says women are the source of entertainment in films.

The major finding as evidenced by respondents' responses to a question about whether they believe women are the source of entertainment in films, which $80 \%$ agreed with while only $20 \%$ disagreed with, as Fig 3 illustrates. According to the survey, $50.91 \%$ respondents believe that the woman's attire is what motivates men to continue committing crimes. On the other hand, $49.09 \%$ expressed disagreement with this statement, as it is reflected in Fig 4. As Fig 5 illustrates, the majority respondents $(80 \%)$ stated that referring to women as "MAAL" has become a trend as an impact of the Bengali films.

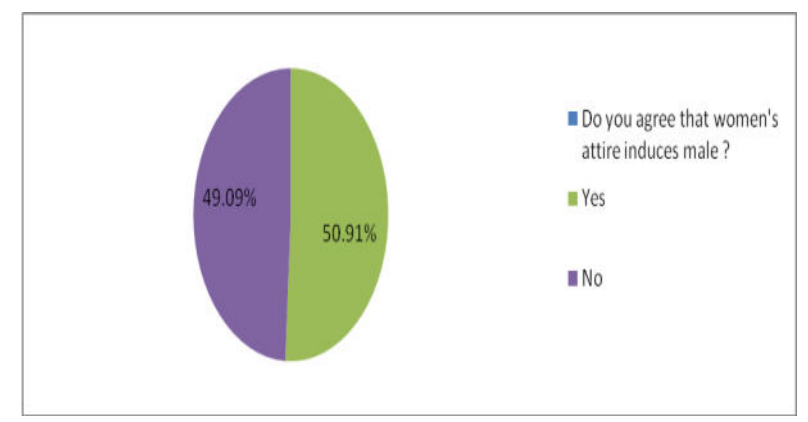

Fig 4: $50.91 \%$ believes women's attire induces male.

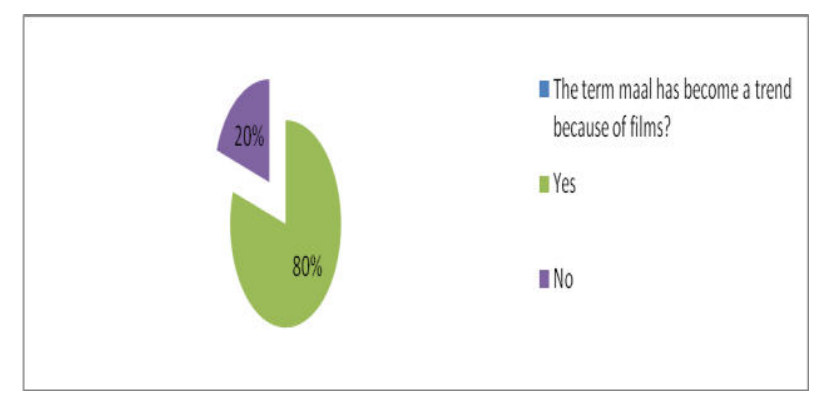

Fig 5: Films popularized the term " $M A A L$ " for women.

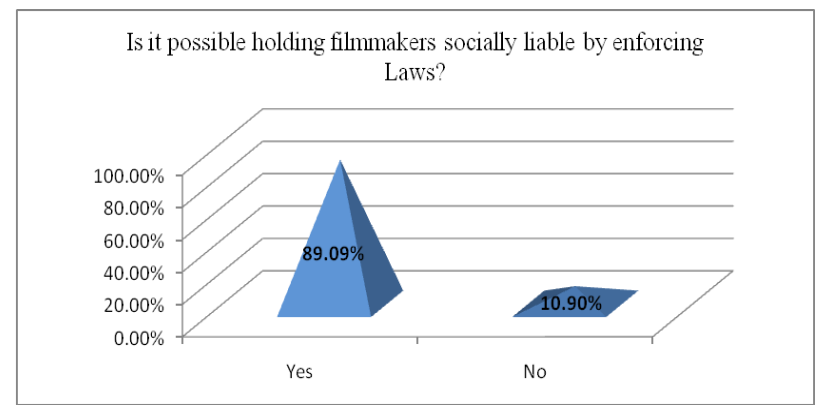

Fig 6: Social responsibility of filmmakers by enforcing laws.

While $89.09 \%$ believe that it is possible to hold producers socially accountable through the enforcement of laws, $10.09 \%$ believe that enforcing new laws to hold them accountable will have no effect on the current situation. This is demonstrated through Fig 6 above. As Fig 7 shows, 95.9\% believe filmmakers should exercise social responsibility. They are innately responsible and obligated to society. Only 4 . $09 \%$ indicated a negative response.

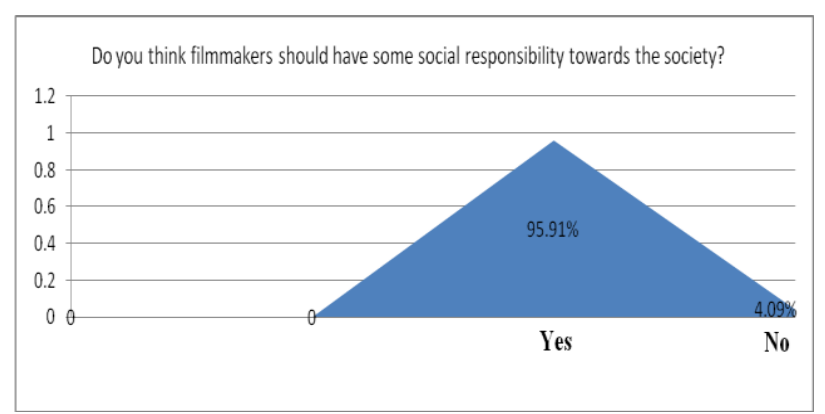

Fig 7: Filmmaker's social responsibility.

\section{Possible legal recourses for the prevention of rape culture}

\section{Role of censor board\& its underlying problems}

Previously, the word 'censor' refers supervisor or a government official who reviewed books, newspapers, plays, etc. before publication. They used to check for negative content or comments about the state or its laws (Mohiuddin, 2015). Like any other countries around the world, Censorship Act exerciseing its policy and a uniform system of censorship controls the Movies, Telefilms in Bangladesh. As 
per the Bangladesh Censorship of Films, 1977, the Censor Board is given power to supervise films and censor such films that are not fit for public exhibitation e.g., films featuring or containing immoral, indecent or the adversary comments (Rule-13, Bangladesh Censorship of Films). In this context, the immorality or obscenities includes over-emphasizing, glamorizing or glorifying an immoral life, enlisting, depicting immoral nature or indecent portrayal, traditions, customs or culture. On these just-mentioned grounds the Censor Board can censor certain contents of the films. The law is not too rigid about these grounds. Though we have laws and policies to censor immoral and adversary contents, the rules are not being followed properly or monitored whether these rules are properly followed or not. The way movies are portraying women itself is giving a negative message to the society. This should necessarily be taken into account by the Censor Board. It is also argued that restrictions on films may kill the creativity at times or may contradict the right to expression under the International Treaty or Conventions. However, that is not the case here. As it was stated by Freedman C.J.M. in his judicial pronouncement in $\mathrm{R}$ vs Odeon Morton Theatres Ltd and United Artists Corp, (1974) that "the issue of obscenity must be taken into consideration as per the community standard", contents of films should also be taken into consideration. In this case the comm.unity standard should be meant as the society of Bangladesh. Since society at la large in Bangladesh, does not accept obscenity it is very much important that the obscenity or immoral contents or messages must be removed from movies for the betterment.

\section{Laws relating to sexual harassment and rape in Bangladesh}

Rape, sexual harassment is of course addressed in the legal system of Bangladesh. Over the time, several measures were taken to address these issues, though it is not enough. Now in $21^{\text {st }}$ century, we are still applying hundred years' old law enacted during British Colonial period. For instances, Section 509 of the Penal Code 1860 which penalizes acts, words and gestures intended to insult the modesty of a woman or intending that such word or sound shall be heard, or that such gesture or object shall be seen, by such woman, or intrudes upon the privacy of such woman, shall be punished with simple imprisonment (1 year) or with fine, or with both. The problem is that the underlying provision is not effective when it comes to the implementation or enforcement of the same; it is extremely difficult in reality to do so owing to multifarious reasons e.g. lengthy process, lack/delay in justice. To address this problem under the provisions of Penal Code, Nari-O-Shishu Nirjatan Daman Ain was adopted in 2000. Section 10 of the Nari-O-Shishu Nirjatan Daman Ain 2000 criminalised the act of someone touching a woman or child (with any part of their body or an object) or "violating a woman's modesty" to "illegally satisfy their sexual desires" (Section-10, Nari O Shishu Nirjaton Daman Ain, 2000). The wordings of these provisions invite sexiest biases towards the women and further victimize them (Huda, 2019). Furthermore, we are still upholding a 150-year-old definition of rape given in the Penal Code, 1860. At present, the law recognizing the rape, Nari O Shishu Nirjaton Daman Ain 2000 also lays down the definition of rape that is given in Penal Code. Neither of these two laws defines or illustrates the concept of consent and penetration. As such, rape is said to have committed only when it happens in the only recognized form of rape under the governing laws in Bangladesh. The definition does not even compass the concept of marital rape which a serious in Bangladesh (Siddiqui, 2021). To address rape legally, Bangladesh needs a definition that includes coerced sexual inter-course, sexual assault, and sexual violence. Instead of ensuring death penalty for the guilty of rape offence, we need to consider redefining rape for the purpose of including all forms of non-consensual penetration, regardless of the perpetrator's or victim's gender.

\section{Examples of legal actions taken against the pro- ducers/ Film Maker}

Previously it was unthinkable to take any legal actions against the production house or film makers for putting any individual or any social groups in a degrading position, the time has changed now. Earlier, people did not bother much about what is being shown in movies. Now, film makers can be held liable when it is proven that they have hurt the sentiments of the people at large. Very recently in Bangladesh, the legal action against the fiction makers will be implemented on the basis of the Bangladesh governments 'Rights and Protection of Persons with Disabilities Act, 2013' for spreading severe negative propaganda about the sensitive matter, which elevated the already existing superstitions, stigma and negative mindset regarding the children with special needs-especially in the rural area (UNB, 
Daily Star, 2021). The fiction was immediately removed from CMV's YouTube channel and other mainstream media platforms due to its deception and underlying message that belittled and insulted the families who have been fighting for constantly to protect their especially able children.

\section{Social responsibilities of the filmmakers}

As a human being, there is no escape route for the filmmakers to social responsibilities which they incur by birth. Films have the ability to convey a story/ message via both audio and visual to convey a story. It has the ability to dictate society, allowing films its' audience to imagine and fill in the blanks of any story. Some movies reflect upon our lives, some are sure-shot soul-stirrer. The power of cinematic media in no certain terms can be denied, and so do the responsibility of the film makers. They must remember that with this fascination comes a huge responsibility towards the society. A great number of moviemakers fail to realize this (UK Essays, 2018).

A filmmaker always tries to evoke an emotion or response from the audience. The moral responsibility of a filmmaker must lie within because only they can decide as to what is worth to be shown and what is not. Some filmmakers feel that a response by society be it positive or negative gives meaning to their film. But what they fail to realize is that a film can be a dangerous tool like any medium and the ability for the filmmaker to navigate the line of moral responsibility to society with society's own reality should be a careful and conscious issue at the forefront of any film (Paul, 2018).

\section{CONCLUSION:}

Films basically represent society and social trends of the country in context. Bengali films are no different. Even though Bangladesh has film censorship Act, it is not effective for multifarious reasons. Our laws prohibiting rape are a big failure. Even though these laws have managed to punish the perpetrators somewhat, such rules or regulations do not help to change a person's perception about women. It is unfortunate that neither of these laws has managed to decrease the rate of rape nor have these been able to change the general outlook towards the act. Therefore, before changing or amending laws aiming to prevent rape, first, it is the perception of the people that needs to be reformed. Accordingly, it is recommended that national Censor Board should vigorously monitor whether a movie contains any material that might have negative impact on creating social perception about women. It is also suggested to introduce a double monitoring system before approving any movie available for public. Besides, it is important to ensure that the members of the Censor Board are well qualified to perform their job. It is one of the weaknesses that Bangladesh's existing law accepts that a highly qualified political person with no knowledge about movies can be a member of the Censor Board. In this regard, these study suggests that the national Censor Board of Bangladesh must be formed with competent members. Otherwise, the board will continue failing to implement the ultimate purpose of national censorship Act.

\section{ACKNOWLEDGEMENT:}

I would like to acknowledge and give my warmest thanks to my supervisor Assistant Prof. Dr. Mahatab Uddin Shawon for his insightful and valuable suggestions and development of this particular research and made this work possible. His generosity in sharing his time has been greatly appreciated. I would also like to give my special thanks to my family and friends as a whole for their continuous support and understanding while writing this paper. My special thanks to my father A.B.M. Shareatur Rahman Jibon for his help in conducting the survey for the research. Finally, I would like to thank Almighty for letting me through all difficulties. I always keep on trusting you for my future.

\section{CONFLICTS OF INTEREST:}

The author of the research has no affiliations with or involvement in any organizations or entity with any financial interest (such as honoraria, educational grants, participation in speakers' bureaus, membership, employment, consultancies, stock ownership, or other equity interest, and patent-licensing), or nonfinancial interest in the subject matter or materials covered in this article.

\section{REFERENCES:}

1) Ain O Shalish Kendro, (2017). Violence against Women- Rape: Jan-May', viewed 02 August 2021. http://www.askbd.org/ask/2017/07/16/violencewomen-rape-january-june-2017/

2) Akhter et al. (2005). 'Knowledge, Attitudes, and Practices on Domestic Violence against Women in Bangladesh', American Sociological Association, pp. 25-27. 
3) Akhter, (2015). Putro Akhon Paisawala, Multimedia Production, Bangladesh.

4) Akter MS, Hossain MA, Akter F, Shirin S, and Zalil MA. (2019). A Feministic approach to Nora of Henric Ibsen's A Doll's House, Br. J. Arts Humanit., 1(5), 28-34.

https://doi.org/10.34104/bjah.019.28034

5) Alam \& Hayat, (2015). Bhalobasha Simaheen, $G$ Series Production, Bangladesh

6) Asha Mehreen, (2016). 'Don't forget Tonu', The Daily Star, 26 March, viewed 03 2021, http://www.thedailystar.net/op-ed/dont-forget-to nu-1199116

7) Azad et al. (2011). A study on Socio-Demographic Characteristics of Alleged Sexual Assault (Rape) Cases in Dhaka City , JAMC Bangladesh, 7(2), pp.21-24.

8) Belinda Robinson, (2015). Real-life fight club: The models, marines, and hipsters who illegally do battle on New York's underground fighting circuit', Daily Mail UK, 10 August, viewed 01 June 2021,

http://www.dailymail.co.uk/news/article-316631 7/Real-life-fight-club-models-marines-millionair es-illegally-battle-New-York-s-underground-figh ting-circuit.html

9) Blaine, (2012). 'The Bambi effect: a look at deer culling and residents reactions', Daily Hearald, viewed 01 June 2021,

http://www.dailyherald.com/article/20120210/su bmitted/702109745/

10) Bohner et al. (2009). 'Rape myth acceptance: Cognitive, effective, and behavioural effects of beliefs that blame the victim and exonerate the perpetrator', Wan Publishers, pp. 17-45. https://kar.kent.ac.uk/id/eprint/19819

11) Charles, (2007). 'Reflections on the Use of Foreign Film in the Classroom to Enhance Cross-Cultural Understanding', The J. of $\mathrm{Hu}$ man Resource \& Adult Learning, 3(2), pp.7-9.

12) Davis, D. M, (1990). 'Portrayals of women in prune-tune network television: Some demographic characteristics', Sex Roles: a Journal of Research, 23(5-6), pp. 325-332.

https://eric.ed.gov/?id=EJ420820

13) Demare, D., Briere, J., \& Lips, (1988). 'Violent pornography and self-reported likely-hood of sexual aggression', Journal of Rese-arch in Personality, 22, pp. 140- 153.

https://doi.org/10.1016/0092-6566(88)90011-6
14) Faludi, S., (1991). 'Backlash: The undeclared war against American women', Crown Publishing Group, New York.

https://en.wikipedia.org/wiki/Backlash:_The_Un declared_War_Against_American_Women

15) Faysal YA., and Rahman MM. (2021). Impact of foucauldian discourse on Feminism and postcolonial studies, Br. J. Arts Humanit., 3(1), 1-10.

https://doi.org/10.34104/bjah.021010wf10

16) Feldman, N. S., \& Brown, E. (1984). 'Male vs. female differences in control strategies: What children learn from Saturday morning television'? Paper presented at the meeting of the Eastern Psychological Association, Baltimore.

17) Gazipur Correspondent, (2017). 'Father, daughter commit suicide for justice', The Daily Star, April 30, viewed 03 May 2021, http://www.thedailystar.net/city/father-daughtercommit-suicide-justice-1398526

18) Human Rights Report, (2013). 'Odhikar Report on Bangladesh', viewed 02 August 2021. https://www.fidh.org/IMG/pdf/odhikar_ahr__201 3.pdf

19) Ho \& Stone, (1991). JFK Movie, Studio Canal $S A S$, USA.

20) Hildebrand \& Najdowski, (2015). 'The Potential Impact of Rape Culture on Juror Decision Making: Implications for wrongful acquittals in sexual assault trials', Albany Law Review, 78(3), p.23.

21) Julien, (2013). 'Moscow's Real-life fight club looks insane', Vice, 15 August, viewed 01 June 2021.

https://www.vice.com/en_us/article/8gdaak/russi an-fight-club

22) Kalhan, (2017). 'Suicide Searches Increased After Release of 13 Reasons why', NBC News, 31 July, viewed 10 June, 2021.

https://www.nbcnews.com/health/health-news/su icide-searches-increased-after-release-13-reasons -why-n788161

23) Keynan, (2016). 'Real life 'Fight Club' reveals brutal street battles in Thailand, Blood is spilled and bones cracked', Mirror, 25 August, viewed 01 June 2021.

https://www.mirror.co.uk/news/world-news/reallife-fight-club-reveal-8701454

24) Khan, (2017). Shaitan Dhora Khaise, J.K. Multimedia Production, Bangladesh. 
25) Kogacioglu, (2004). 'The Tradition Effect: Framing Honor Crimes in Turkey', differrences: A Journal of Feminist Cultural Studies, 15( 2), pp. 118-51.

http://dx.doi.org/10.1215/10407391-15-2-118

26) Linson \& Fincher, (1999). Bambi Movie, Fox 2000 Pictures, USA.

27) Lonsway \& Fitzgerald, (1999). Rape Myths: In Review, Psychology of Women Quarterly, 18(2), p.134.

28) Martha, (1980). Cultural Myths and Supports for Rape, Journal of Personality and Social Psychology, 38(2), pp. 217-230. https://doi.org/10.1037/0022-3514.38.2.217

29) Mohiuddin, (2015). 'Administration and the Rules, Regulations of Censorship: A study on Bangladesh Film Censor Board (BFCB)', IOSR Journals, 17(6), ver. I, p. 38.

30) M. S. Siddiqui, (2021). The Need for a Comprehensive Definition of Rape, The Daily Star, 19 January, viewed 01 October 2021, https://www.thedailystar.net/law-our-rights/news the-need-comprehensive-definition-rape-203034 $\underline{5}$

31) Matthew Spaul, (2014). A Filmmakers Responsibility, North light Productions, viewed 04 June 2021.

http://www.northlightpro.com/digital-den/2014/ 3/20/a-filmmakers-responsibility

32) National Archives, (2019). 'JFK Assassination Records Review Board', National Archives, 4 June, viewed 10 June, 2021.

https://www.archves.gov/research/jfk/review-bo ard

33) News Correspondent, (2009). 'Raped Girl Lashed 100 times', The Daily Prothom Alo, 08 June, viewed 04 May 2021.

http://eprothomalo.com/index.php?opt=view\&pa $\mathrm{ge}=1 \&$ date $=2009-06-08$
34) Pila, (2018). 'The Value of Authorship in the Digital Environment' in William H Dutton and Paul W Jeffreys (eds), World Wide Research: Reshaping the Sciences and Humanities in the Century of Information, MIT Press 2010, pp. 8

35) Robert \& Douglas, (1995). Film History, Theory and Practice, New York: Knopf, New York City, New York, U.S.

36) 'Report Sent by Local Human Rights Defender associated with Odhikar from Jhenaidah', (2016). Prothom Alo, October, viewed 02 April 2021.

www.prothom-alo.com/bangladesh/article/10077 $\underline{13 /}$

37) Sheikh, (2010). 'Rapist Spared, Victim Lashed,' The Daily Star, 24 January, viewed 04 2018.

https://www.thedailystar.net/news-detail-123248

38) Taqbir, (2009). Sexual harassment and the law: Where's the problem? The Daily Star, 27 June, viewed 01 October 2021, https://www.thedailystar.net/opinion/humanrights/news/sexual-harassment-and-the-lawwheres-the-problem-1762759

39) UK Essays, (2018). General ethics in film making, viewed 16 November 2021.

https://www.ukessays.com/essays/film-studies/g eneral-ethics-relating-to-film-making.php?vref= $\underline{1}$

40) UNB, (2021). Legal actions will be taken against the creators of 'Ghotona Shotto', The Daily Star, 10 August, viewed 01 October 2021.

https://www.thedailystar.net/entertainment/tv-fil $\mathrm{m} /$ news/legal-actions-will-be-taken-against-thecreators-ghotona-shotto-2149106

41) Warshaw \& Parrot, (1991). 'The Contribution of Sex-Role Socialization to Acquaintance Rape, in Acquaintance Rape: The Hidden Cime', Berkeley Journal of Sociology, pp.75.

Citation: Disha JS. (2021). Contemporary mainstream Bengali movies and societal perceptions towards rape: legal perspectives, Asian J. Soc. Sci. Leg. Stud., 3(6), 247-255.

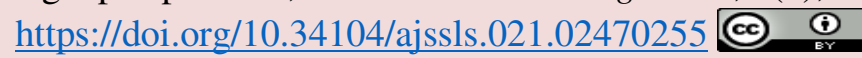

